\title{
ANALYSIS OF ATHLETES' RUNNING ABILITY DATA \\ MINING ALGORITHM BASED ON THE DYNAMIC CHARACTERISTICS OF FOOTBALL PLAYERS
}

\author{
ANÁLISE DO ALGORITMO DE MINERAÇÃO DEDADOS DA CAPACIDADE DE CORRIDA DE ATLETAS COM \\ BASE NAS CARACTERÍSTICAS DINÂMICAS DOS JOGADORES DE FUTEBOL
ANÁLISIS DEL ALGORITMO DE MINERÍA DE LA CAPACIDAD DE CORRER DE LOS JUGADORES DE FÚTBOL BASADO EN LAS CARACTERÍSTICAS DINÁMICAS DE LOS JUGADORES DE FÚTBOL

\section{Long Zhang' (D) \\ (Public Health Education)}

1. Shanxi Institute of Technology, Shanxi, Yangquan, 045000, China.

Correspondence:

Shanxi, Yangquan, 045000, China. qcnpzz209yi403@126.com.

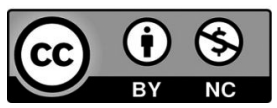

\begin{abstract}
In 2008, our country successfully held the Olympic Games, where China won the most gold medals. After these Olympic Games, China has also become a world sports power. Our country's table tennis, diving, skating and other sports are also in the leading ranks in the world. In this study, according to the current training status of Chinese football players, we used data mining algorithm to analyze the unawareness of acceleration and speed of Chinese athletes in the running process. In this study, these indicators were quantified and analyzed, which has successfully promoted the training level of Chinese football players.
\end{abstract}

Keywords: Football; Data Mining; Running.

\section{RESUMO}

Em 2008, nosso país sediou os Jogos Olímpicos, em que a China ganhou a maior parte das medalhas de ouro. Após os Jogos Olímpicos, a China também se tornou uma potência esportiva mundial. O tênis de mesa, o salto ornamental, a patinação e outros esportes também estão em posições de liderança. Neste estudo, de acordo com o atual estado de treinamento dos jogadores de futebol chineses, usamos o algoritmo de mineração de dados para analisar a falta de aceleração e velocidade dos atletas chineses na corrida. No estudo, esses indicadores foram quantificados e analisados, elevando o nível do treinamento dos jogadores de futebol chineses.

Descritores: Futebol americano; Mineração de Dados; Corrida.

\section{RESUMEN}

En 2008, China celebró con éxito los Juegos Olímpicos.China ganó la mayoría de las medallas de oro en los Juegos Olímpicos.Después de los Juegos Olímpicos, China también se ha convertido en una potencia deportiva mundial.El tenis de mesa, el buceo y el patinaje sobre hielo en China también están en la posición de liderazgo en el mundo.De acuerdo con la situación actual del entrenamiento de los jugadores de Fútbol en nuestro país, este trabajo analiza la falta de percepción de la aceleración y velocidad de los jugadores de Fútbol en el proceso de correr con el algoritmo de minería.Y en los resultados de la investigación, el análisis cuantitativo de estos indicadores ha mejorado con éxito el nivel de entrenamiento de los jugadores de fútbol chinos.

Descriptores: Jugador de fútbol; algoritmo minero; capacidad de corer.

\section{INTRODUCTION}

Since China's comprehensive national strength has been greatly improved after its reform and opening up and accession to the WTO, China has changed its strategy after entering the twenty-first Century, and should pay attention to the comprehensive improvement of the comprehensive national strength. Therefore, in the first ten years of twenty-first Century, our country has set up the expected target, and we should move our sports industry to a new height. ${ }^{1}$ Although the sports industry in our country is in a flourishing stage, there is only one heterogeneous sport in China: the football industry in China. ${ }^{2}$ Football originated in China's Song Dynasty Cuju, a way to start just for entertainment in the high officials and noble lords, and then gradually spread to the general public. After this movement was introduced abroad, it evolved into the modern football movement at the present stage after a long period of evolution. ${ }^{3}$ Modern football originated in Britain, and Britain has a great interest in this sport. In Britain, children are proud to play football. Because of this movement for human body and physical requirements, and is a competitive sport, after nonprofessional football will lead to a serious collapse, so for this objective reason, compared to other Asian races will appear on the body of the congenital weakness, the weak through the development of science and technology although it is made up of some, but did not enhance the quality. ${ }^{4}$ China's modern football originated in the world in 60s, and in 80s had a world cup kick. But in the next 30 years, our football has never had any potential athletes. These are related to our country's less investment in science and technology. ${ }^{5}$

In view of the above problems in our football, besides our national physique, our players' training lacks systematicness and scientificity, which is also an important relationship. ${ }^{6}$ Traditionally, many unsuitable players have been placed in their inappropriate position, leading to a low level of football in our country.? 


\section{METHODOLOGY}

Analysis Process Construction of Athletes' Running Ability Mining Algorithm Based on the Dynamic Characteristics of Football Players

The research on the dynamic characteristics of football players'running is not new. As early as in the 90s of last century, some scholars studied the dynamic characteristics of football players'running. At that time, because the technology is not developed, the lack of related equipment, so that when the data are collected in the laboratory, and the final data is not very accurate, there is a great difference in the actual competition and dynamic characteristics of football players is running. But even if the data is not very accurate, but the report run dynamic characteristics affect the football player or for the sports industry formed a sensation, because this is the first time someone from the perspective of data for the sports test, although the test value is not high, but to open the use of scientific means to study sports precedent. Since the report, a large number of people have begun to use these methods to carry out the research of sports. Compared with foreign countries, our country did not improve the running ability of the players to test the tracking device, intelligent football coaches in China rely on their own eyes are the advantages and disadvantages of player evaluation, as can be imagined, this evaluation must be advanced scientific instruments accurately, this leads to the blank of Chinese soccer coaches cannot conduct a comprehensive understanding for me Chinese players. Later, because the technology has made great progress, so the previous research using scientific means to carry out sports gradually become a reality, in this study we use the mining algorithm for dynamic characteristics of running football players running ability of mining. This is not only the calculation function of mining using this algorithm, the data acquisition is also used high-speed camera and other advanced technology, the combination of these techniques to realize the dynamic characteristics of running our football players running ability based on mining algorithm analysis. The following table is the weight level questionnaire of the dynamic characteristics and the level of running ability of the athletes in each movement. (Table 1)

You can clearly see from the dynamic characteristics of running and running ability of the athletes in various sports level in the weight level questionnaire we weight, the dynamic characteristics of the athletes running and running ability level in football, basketball, badminton, table tennis four sport values are very high, this is because the four kinds of sports require athletes running. These data also illustrate from the side that our test for dynamic performance and running ability of soccer players is not only required by football players, but also urgent for other sports. From the above table, we can clearly see that athletes' running dynamic characteristics and running ability level are very low in the sport of table tennis. This is because the sport does not need a lot of physical running, but just in situ. From the above table, we can see that in the four sports in the table above, the highest weight of running and running ability of athletes is football, because football is a very physical exercise. The athletes around the football field is 400 meters in circumference has been moving, the match will be more than an hour, many players often need more than one hour in the different running, which is also the reason why the top of the table is the dynamic characteristics of athletes running and the level of weight of running ability is the highest.

The dynamic characteristics of running football athletes running ability of mining process constructed mainly by a high-speed camera to capture data, determine the clustering number, the clustering threshold set mining, clustering mining, calculate the sample average and incremental

Table 1. The weight level questionnaire of the dynamic characteristics and running ability of athletes in each movement.

\begin{tabular}{c|c|c|c|c}
\hline & Football & basketball & badminton & table tennis \\
\hline $\begin{array}{c}\text { Dynamic characteristics } \\
\text { of athletes' running }\end{array}$ & $66 \%$ & $78 \%$ & $62 \%$ & $75 \%$ \\
\hline Running ability level & $94 \%$ & $74 \%$ & $95 \%$ & $83 \%$ \\
\hline
\end{tabular}

global weighting algorithm based on part analysis. A football coach can choose the appropriate position of football players according to their physiological characteristics, or use these data to present the advantages and disadvantages of football skills. Then they use these data to focus on the usual guidance of football players. The analysis process of the running ability mining algorithm based on the dynamic characteristics of football players is made up of the following steps: One is the capture of data by a high-speed camera. In this study, we used high-speed cameras to capture dynamically the football players in running process. We can directly input data to the database captured by high-speed cameras, and then these data can be directly used. The two is to determine the number of clustering mining. There are many different types of football players running dynamic characteristics of our high-speed camera to capture, including the motion state of athletes' leg, arm, thigh muscle, leg muscle, biceps muscle group, we in this step-in accordance with these types of classification, we divide these species is our clustering number; The three is to set the clustering threshold mining. After we finished in the determination of the number of clustering mining, the next part is the mining of our clustering threshold, these clustering threshold parameters for the final evaluation of the results of our tests we have an important role, so in this part we need the clustering threshold value iteration to reduce the error. The four is the average value of the calculated sample. We use clustering mining algorithm to calculate all kinds of data after classifying in the second part, and we calculate the mining results of each category. But these results are single and not all, in the next section we calculated the average value of the samples, we calculated the comprehensive of each athlete's physical exercise capacity on average, finally use the related results of physical exercise capacity for each athlete's average of the complete and comprehensive presentation, this is equivalent to a draft has been completed. The five is the global weighted processing of the incremental results. After the above part is completed, we calculate the incremental results of all the times, but the weight values of these incremental results are different. These weight values are also important in determining that part, so in this part, we deal with the global weighting of the results of our calculations. Based on the dynamic characteristics of football players running ability mining algorithm analysis process analysis flow chart is shown in Figure 1.

\section{RESULT ANALYSIS AND DISCUSSION}

After the above process design and algorithm analysis on clustering algorithm and calculation formula of partially completed mining characteristics of football players running dynamic players running ability based on, then we need to we design the algorithm model and clustering algorithm and characteristics of running football players running ability of dynamic mining based on test. In the process of this test, we used four football players to do the test. The data in the table below are collected data in the actual game, so as to ensure the true reliability of the four football players' body cloud top data. First, we test the running ability of our athletes based on the running characteristics of the football players. The results are shown in Table 2.

We can see clearly from the results of the test result table of the athletes running ability mining algorithm based on the dynamic characteristics of the footballers. The above four athletes are different in their own athletic abilities, such as legs, arms, thigh muscles, calf muscles and biceps. Athlete A has more developed thigh muscles, so the score in the algorithm model of running ability of athletes based on the running characteristics of football players is higher. The athlete B calf muscle is developed, which has accelerated to its strong in practice, found that $B$ in the athletes to speed up the time very quickly in the practical test, which helps athletes for football steals, so the player is in reality as the center, Athlete $C$ has developed biceps brachii. We know that biceps brachii is an arm muscle group. This athlete is deficient in other abilities, so in actual football match, this athlete is a goalkeeper. We use the four 


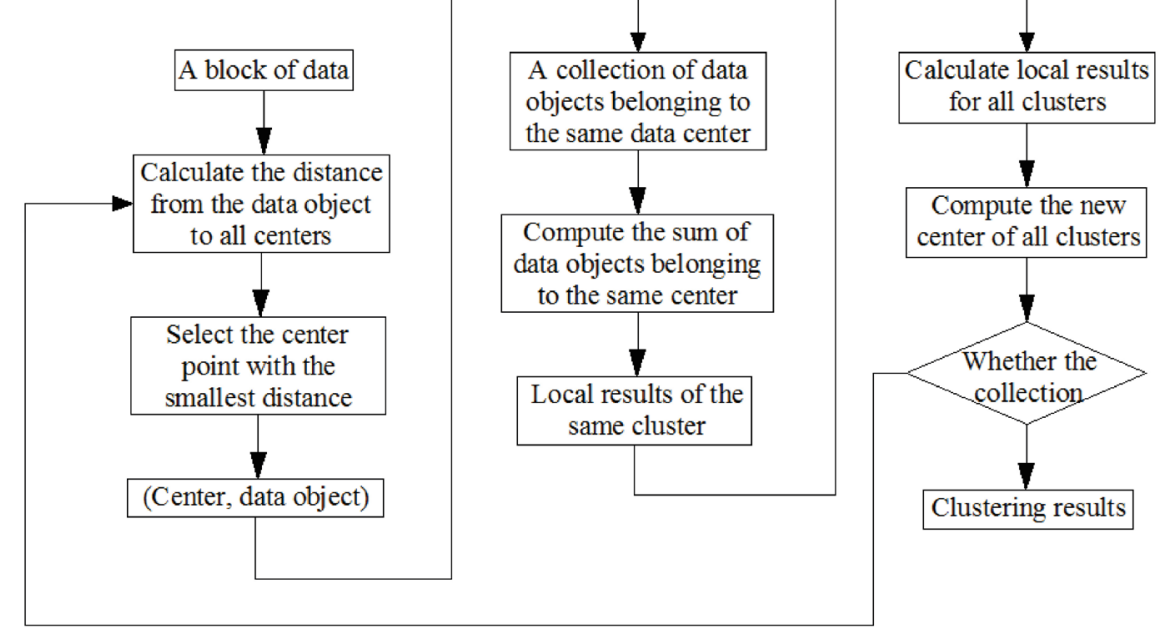

Figure 1. Analysis of the running ability of athletes based on the dynamic characteristics of football players.

football players in the practice of the running ability of data input into the model to calculate, get on the table, in the next section, we are going to use the clustering mining algorithm for test, to examine its use in practice is not good. The following are the results of the clustering mining algorithm. We used three bit athletes to test the results. (Figure 2)

Show us the calculation results from the mining algorithm of clustering map, the running ability data of three football players we use in the course of the study, we use clustering algorithms for data calculation, we found that the clustering algorithm in large fluctuations In this paper, we show the results from the mining algorithm of clustering map, the running ability data of three football players we use in the course of the study, we use clustering algorithms for data calculation, we found that the clustering algorithm has

Table 2. An algorithm model test result table for athletes' running ability mining based on the dynamic characteristics of football players.

\begin{tabular}{c|c|c|c|c|c}
\hline & Legs & arms & thigh muscles & calf muscles & biceps brachii \\
\hline A & 8.7 & 9.7 & 7.6 & 4.6 & 9.6 \\
\hline B & 9.2 & 7.6 & 7.0 & 5.6 & 4.6 \\
\hline C & 8.8 & 8.6 & 7.2 & 2.6 & 2.6 \\
\hline D & 8.4 & 8.3 & 6.6 & 1.6 & 8.0 \\
\hline
\end{tabular}

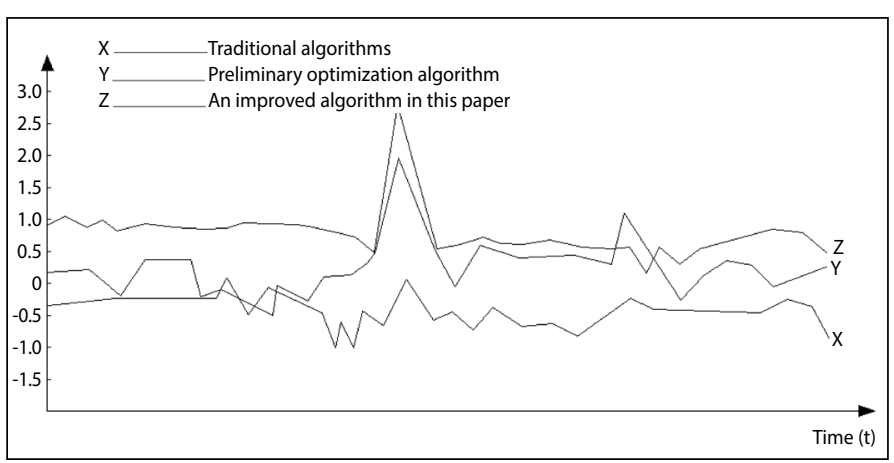

Figure 2. The calculation result diagram of clustering mining algorithm. great fluctuation. But the strange thing is that volatility did not affect the computation time of our clustering algorithm, we found that at the end of the study, this volatility is because our clustering algorithm is one of the parameters of the input error led to fluctuations, in later studies, we for the parameters of the effective regulation. To avoid this kind of fluctuation.

\section{CONCLUSION}

The dynamic characteristics of running football players running ability based on the mining process constructed mainly by a high-speed camera to capture data, determine the clustering number, the clustering threshold set mining, clustering mining, calculate the sample average and incremental results global weighting component analysis algorithm. This paper proposes an incremental clustering algorithm is applied to the running ability of football athletes training according to the characteristics of data mining, football running dynamic and large amount of data, based on the existing clustering results, the incremental clustering algorithm is modified to avoid the existing results, each update data on the whole data clustering problems, improve the efficiency of clustering. At the same time, in view of the practical application, we add the weighted processing module to avoid the data migration. Four football players were tested. The data in the table below were collected from the actual matches, which ensured the true reliability of the four football players' body data. The experiment shows that this algorithm can make a dynamic and real-time mining classification for the running ability of football training athletes, which is more objective and intelligent and significant.

\section{ACKNOWLEDGMENT}

The 13th five year plan of Education Science in Shanxi Province. The name of project:The Implementation of Football League mechanism in Colleges and Universities (GH18118).

The author declare no potential conflict of interest related to this article

AUTHORS' CONTRIBUTIONS: The author has completed the writing of the article or the critical review of its knowledge content. This paper can be used as the final draft of the manuscript. Every author has made an important contribution to this manuscript. Long Zhang: writing and execution.

\section{REFERENCES}

1. Wang CJ, Jia D, Lei SG, Mu SG. Analysis of dynamic characteristics of vegetation in semi-arid mining area based on time trajectory segmentation algorithm. Meitan Xuebao/Journal of the China Coal Society. 2017:42(2):477-83.

2. Ivarsson A, Stenling A, Fallby J, Johnson U. The predictive ability of the talent development environment on youth elite football players'well-being: A person-centered approach. Psychology of Sport \& Exercise. 2014;16:15-23.

3. Lei T, Li H, Xie H, Feng S. Analysis of chaotic runoff data based on chebyshev polynomials local model. Metallurgical \& Mining Industry. 2015;7(6):250-8

4. Perroni F, Vetrano M, Camolese G, Guidetti L, Baldari C. Anthropometric and Somatotype Characteristics of Young Soccer Players: Differences Among Categories, Subcategories, and Playing Position. J Strength Cond Res. 2015;29(8):2097-104

5. Hogarth LW, Burkett BJ, McKean MR. Activity profiles and physiological responses of representative tag football players in relation to playing position and physical fitness. PLoS One. 2015;10(12):e0144554.

6. Hammami R, Granacher U, MakhloufI, Behm DG, Chaouachi A. Sequencing effects of balance and plyometric training on physical performance in youth soccer athletes. J Strength Cond Res. 2016;30(12):3278-89.

7. de Hoyo M, Sañudo B, Carrasco L, Mateo-Cortes J, Domínguez-Cobo S, Fernandes O, et al. Effects of 10-week eccentric overload training on kinetic parameters during change of direction in football players. J Sports Sci. 2016;34(14):1380-7. 